\title{
SUVREMENI PRISTUPI U PROMATRANJU POSLOVNE USPJEŠNOSTI IZ PODUZETNIČKE PERSPEKTIVE
}

\begin{abstract}
Sažetak
Mjerenje poslovne uspješnosti još uvijek predstavlja značajan izazov, kako za znanstvenu tako i za poslovnu zajednicu. Empirijska istraživanja jasno ukazaju na multidimenzionalnost samog koncepta, međutim ne pružaju suglasnost koje točno dimenzije čine koncept poslovne uspješnosti. Ciljevi rada su: (1) prikazati detaljan pregled literature povijesnog razvoja koncepta poslovne uspješnosti uvažavajući tradicionalne i suvremene poglede, (2) pružiti osnovni pregled prednosti i nedostataka različitih mjera uspješnosti te (3) pružiti detaljan opis koncepta poslovne uspješnosti unutar poduzetničkog konteksta, pri čemu je naglasak stavljen na najznačajnije pristupe proučavanja poslovne uspješnosti. Može se zaključiti da literatura i dalje ne pruža jedinstven i nedvosmislen pogled koja je to „najbolja” mjera poslovne uspješnosti, niti pruža jasno definiran model kojim bi se poslovna uspješnost mogla u potpunosti iskazati. Rad je namijenjen široj akademskoj i poslovnoj zajednici zainteresiranoj za proučavanje koncepta poslovne uspješnost i njezine teorijske i praktične primjene.
\end{abstract}

Ključne riječi: poslovna uspješnost, pokazatelji uspješnosti, multidimenzionalnost, poduzetništvo

\section{Uvod}

Mjerenje uspješnosti poslovanja bilo je i još uvijek je značajan izazov za istraživače. Poslovna uspješnost služi kao potpora strateškom menadžmentu pri provedbi strateških ciljeva pružajući uvid u poslovne aktivnosti poduzeća. Mjerenje uspješnosti najčešće se vezuje uz vrednovanje zaposlenika, međutim ono je mnogo širi, multidisciplinaran i krosfunkcionalan pojam koji se odnosi na sva područja i sve razine organizacije (Marr i Schiuma, 2003). Uobičajen pristup mjerenju poslovne uspješnosti odnosi se na mjerenje profitabilnosti promatrano kao povrat na investicije (ROI). Međutim, mnogi istraživači (Neely et al., 2005; Abu-Jarad et al., 2010; Vij i Bedi,

izv. prof. dr. sc. Bojan Morić Milovanović, Institut za javne financije, Zagreb, bojan.moric@ijf.hr 
2016) kritizirali su pouzdanost povrata na investicije kao jedinog indikatora poslovne uspješnosti. Glavna zamjerka uporabi isključivo tog kriterija odnosi se na činjenicu da se kratkoročni profiti mogu napuhati na uštrb dugoročnog rasta.

Najučestalije mjere financijske uspješnosti odnose se na povrat na imovinu (ROA), povrat na investicije (ROI), povrat na kapital (ROE), rast prodaje, bruto profit i dodana vrijednost (Orsag, 2011). Rast prodaje, profit i slični financijski pokazatelji značajni su ciljevi malih i srednjih poduzeća pri čemu razina ostvarenja navedenih pokazatelja predstavlja mjeru uspješnosti poslovanja (Cavusgil i Zou, 1994). Wiklund (1999) smatra da zajedničko promatranje rasta i financijske uspješnosti predstavlja bolji način prikazivanja stvarne poslovne uspješnosti nego što bi to svaka mjera zasebno pokazivala. S druge strane, nefinancijske mjere uspješnosti mogu uključivati tržišni udio, stopu zadržavanja kupaca, reputaciju i društvenu odgovornost poduzeća (Antoncic i Hisrich, 2003).

Brojni istraživači naglasili su da je pri istraživanju poslovne uspješnosti potrebno koristiti višestruke aspekte uspješnosti (Lumpkin i Dess, 1996; Venkatraman i Ramanujam, 1986), pri čemu Chakravarthy (1986) inzistira na multidimenzionalnom pristupu istraživanja uspješnosti. Lumkin i Dess (1996) smatraju da poduzetnički proces može dovesti do pozitivnog rezultata u jednoj dimenziji uspješnosti, dok u nekim drugim dimenzijama može dovesti do negativnih rezultata. Primjerice, veliko investiranje resursa u dugoročne projekte može dovesti do umanjenja kratkoročne uspješnosti. Potrebno je pri analizi provedbe strateškog plana primjenjivati višestruke mjere koje uključuju financijske i nefinancijske pokazatelje kako bi se postigla šira i razumljivija slika poslovne uspješnosti (Murphy et al., 1996).

U nastavku rada detaljno je elaboriran koncept poslovne uspješnosti unutar poduzetničkog konteksta. Poslovna uspješnost promatrana je kroz razne aspekte poduzetničkog djelovanja, kao što su: računovodstveni, financijski, marketinški, operativni i logistički, čime je pružena cjelokupna i zaokružena slika proučavanja tog koncepta.

\section{Poslovna uspješnost: teorijski okvir}

Znanstvena literatura iz područja poduzetništva i strateškog menadžmenta pruža razne konceptualizacije poslovne uspješnosti, pri čemu poslovnu uspješnost promatra kroz dvije ključne perspektive: (a) za čije interese poduzeće posluje te (b) koje su to dimenzije koje treba mjeriti (Carton i Hofer, 2006). Drucker (1954) smatra da je opstanak poduzeća krajnja mjera poslovne uspješnosti te je stoga predložio osam različitih dimenzija uspješnosti za koje smatra da su ključni za opstanak i razvoj poduzeća: (a) tržišni položaj poduzeća u odnosu na njegov tržišni potencijal, (b) inovacije, (c) produktivnost, (d) fizički i financijski resursi, (e) profitabilnost dovolina da pokrije premiju rizika poslovanja, (f) učinak i razvoj menadžera, (g) učinak i stav zaposlenika 
te (h) društvena odgovornost. S druge strane, prema Ansoffu (1965) povrat na ulaganje (ROI) predstavlja ultimativnu mjeru poslovne uspješnosti, Freeman (1984) smatra da poduzeće pri realizaciji svojih poslovnih ciljeva treba uzimati u obzir i ciljeve svih dionika, dok Porter (1985) tvrdi da ciljevi poslovnih jedinica moraju odražavati ciljeve cjelokupnog poduzeća.

Venkatraman i Ramanujam (1986) smatraju da se poslovna uspješnost može razložiti na tri osnovna aspekta: (a) financijska uspješnost, (b) operativna uspješnost te (c) utjecaj dionika. Financijska uspješnost odnosi se na cjelokupni financijski učinak poslovanja te se promatra u terminima profitabilnosti, rasta, učinkovitosti, financijske strukture, opstanka poduzeća, novčanih tijekove te akumulacije resursa. Operativna uspješnost bavi se nefinancijskim pitanjima poslovanja, kao što su: razvoj tržišta, razvoj organizacije, umrežavanje, kvaliteta proizvoda, inovacije te zadovoljstvo zaposlenika i kupaca. Također, naglašavaju da interesi svih dionika trebaju biti obuhvaćeni prilikom definirajnja mjera poslovne uspješnosti kako određene interesne skupine ne bi bile zakinute.

Dess i Robinson (1984) uspoređivali su korisnost subjektivnih mjera uspješnosti u odnosu na objektivne mjere uspješnosti, kao što povrat na imovinu (ROA) i rast prodaje, pri čemu su utvrdili da je subjektivna procjena uspješnosti poslovanja povezana s objektivnim mjerama, što sugerira da se za mjerenje poslovne uspješnosti ne moraju isključivo koristiti objektivne mjere uspješnosti. Brush i Vanderwerf (1992) u svojem su istraživanju ustanovili kako postoji trideset i pet različitih mjera uspješnosti koje je moguće pronaći u literaturi što ukazuje na činjenicu da ne postoji konsenzus koje točno mjere je moguće koristiti da bi se ustanovila poslovna uspješnost. Najčešće korištene mjere uspješnosti vezane su uz razinu prodaje, opstanak poduzeća, promjene u broju zaposlenika te profitabilnost, usto objektivne mjere bile su znatno više korištene nego subjektivne mjere (Brush i Vanderwerf, 1992). Sukladno rezultatima koje su ustanovili Brush i Vanderwerf (1992), Murphy et al., (1996) također su ustanovili da ne postoji konsenzus o mjerama korištenim za mjerenje poslovne uspješnosti, pri čemu su pregledom postojeće literature identificirali ukupno sedamdeset i jednu različitu mjeru korištenu za mjerenje poslovne uspješnosti. Te mjere klasificirali su u osam zasebnih dimenzija: učinkovitost, rast, profit, veličina/likvidnost, uspjeh/neuspjeh, tržišni udio, zaduženost, i druge.

Kumarasinghe i Hoshino (2010) smatraju da mjerenje poslovne uspješnosti i dalje predstavlja kontroverzu u istraživanjima iz područja menadžmenta i poduzetništva, pri čemu Marr i Schiuma (2003) kao jedan od osnovnih problema vide raznolikost metoda i pristupa proučavanju teme. Istraživači su poslovnu uspješnost promatrali iz perspektive raznih akademskih disciplina, kao što su računovodstvo, strateški menadžment, upravljanje ljudskim resursima itd. Također, Taouab i Issor (2019) smatraju uspješnost širokim pojmom koji se odnosi na različite pojmove 
kao što su rast, profitabilnost, produktivnost, učinkovitost i konkurentnost, a mjere uspješnosti dijele $u$ četiri kategorije: (a) financijske mjere, (b) nefinancijske mjere, (c) materijalne mjere i (d) nematerijalne mjere. Prema Gimbertu et al., (2010), sustav mjerenja poslovne uspješnosti predstavlja sažet i definiran skup mjera (financijskih ili nefinancijskih) koji omogućuju proces donošenja odluka prikupljanjem, obradom te analizom kvantitativnih podataka. Mjerenje poslovne uspješnosti pruža značajne informacije koje omogućuju menadžmentu praćenje uspješnosti, izradu raznih poslovnih izvještaja, unapređenje motivacije i komunikacije te utvrđivanje ključnih poslovnih problema i izazova (Waggoner et al., 1999).

Tangen (2004) promatra poslovnu uspješnost kroz metrike učinkovitosti i efektivnosti poslovnih akcija koje poduzimaju poduzeća, pri čemu Neely (2007) pod učinkovitošću smatra mjeru ekonomske uporabe resursa poduzeća pri zadovoljavanju određene razine potreba dionika, a pod efektivnošću u kojoj su mjeri ispunjeni zahtjevi dionika. Stoga, Ogunsiji i Ladanu (2017) smatraju kako poslovna uspješnost, odnosno mjere poslovne uspješnosti trebaju biti dizajnirane ili korištene na način da ukazuju na razinu aktivnosti poduzeća u korištenju svojih resursa sa svrhom ostvarenja očekivanja dionika. Drugačije rečeno, prema Ogunsiji i Ladanu (2017) sustav mjerenja poslovne uspješnosti trebao bi moći pružiti odgovore na sljedeća pitanja vezana uz ispunjenje očekivanja svih dionika iz razloga što se u obzir uzimaju prošli, sadašnji i budući poslovni rezultati poduzeća: (a) koliko smo dobro do sada radili, (b) kako sada radimo i (c) možemo li bolje. Lebans i Euske (2006) smatraju da sljedeća obilježja jasnije ilustriraju koncept poslovne uspješnosti: (a) uspješnost predstavlja set financijskih i nefinancijskih pokazatelja, (b) uspješnost predstavlja dinamičan koncept, (c) uspješnost je moguće prikazati korištenjem uzročno-posljedičnog modela, (d) uspješnost je moguće različito tumačiti ovisno o perspektivi osobe uključenoj u procjenu uspješnosti poduzeća, (e) za jasno definiranje koncepta uspješnosti, nužno je znanje temeljnih područja odgovornosti, (f) kvantifikacija rezultata je preduvjet izrade izvještaja uspješnosti poduzeća.

Također, nužno je napomenuti da mjerenje poslovne uspješnosti ima snažnu vremensku komponentu koju je također nužno uzeti u obzir, tj. ono što se promatra ne mora nužno biti „apsolutno” stanje poduzeća, već je više nalik na „snimku” koja promatra samo određenu razinu cjelokupnog stanja u određenom trenutku vremena. Stoga, Siepel i Dejardin (2020) napominju kako poduzeće koje je profitabilno možda neće iskazivati značajno zaposlenje novih radnika, jednako kao što poduzeće koje je visoko inovativno možda neće ostvarivati visoku razinu prihoda (prodaje).

Osim već spomenutih istraživača, Ogunsiji i Ladanu (2017) također navode kako je nužno poslovnu uspješnost promatrati kao multidimenzionalan koncept koji uključuje financijske i nefinancijske aspekte poslovanja. Tangen (2004) ukazuje da se mnoga poduzeća još uvijek oslanjaju na tradicionalne kvantitativne sustave mjere- 
nja financijske uspješnosti, pri čemu se financijska uspješnost najčešće promatra kroz pokazatelje profitabilnosti kojima se izražava snaga zarade poduzeća. Ti pokazatelji ukazuju na značaj nekog modaliteta profita prema veličini angažiranog kapitala, odnosno prema obujmu poslovne aktivnosti izražene veličinom prodaje (Orsag, 2011). Njima se pokazuju ukupni efekti likvidnosti, upravljanja imovinom i dugom na mogućnost ostvarenja profita. Profitabilnost se može mjeriti u odnosu na obujam prodaje i u odnosu na ulaganja te se izražava u postotnim vrijednostima. Orsag (2011) te Mečev i Grubišić (2020) smatraju kako su najčešće korišteni pokazatelji profitabilnosti: marža kontribucije, bruto profitna marža, neto profitna marža, temeljna snaga zarade, povrat na ukupnu imovinu/investicije (ROA ili ROI) te povrat na vlastiti kapital/ dioničku glavnicu (ROE).

Budući da se analiza uspješnosti poslovanja tradicionalno bazirala na promatranju raznih financijskih pokazatelja, pri čemu su se nefinancijski pokazatelji zanemarivali, suvremeno poslovanje nametnulo je potrebu cjelovitog promatranja poslovne uspješnosti iz razloga što financijski aspekti više ne predstavljaju osnovno mjerilo procjene ostvarenja poslovnih rezultata mladih, dinamičnih, brzo rastućih i agilnih poduzeća (Verbeeten, 2005). Dakle, naglasak s pukog analiziranja financijskih izvještaja prebačen je na razne nefinancijske aspekte poslovne uspješnosti (Vrdoljak Raguž, 2010), kao što su: tržišni udio, zadovoljstvo kupaca, ostvarenje strateških ciljeva, društveno odgovorno poslovanje itd. Ovdje je nužno napomenuti da Ittner i Larcker (2003) ukazuju na pogreške koje poduzeća mogu učiniti prilikom procjene nefinancijske uspješnosti:

- nedostatak usklađenosti mjera sa strategijom: ključni izazov za poduzeće jest utvrditi koje su to točno nefinancijske mjere koje je nužno implementirati

- validacija mjerenja: poduzeća često ne validiraju postavljeni mjerni model, što dovodi do mjerenja raznih irelevantnih pokazatelja

- nemogućnost utvrđivanja ispravnih ciljeva i mjera

- pogrešna mjerenja: mnoga poduzeća koriste metrike koje ne zadovoljavaju statističku valjanost i pouzdanost.

Ghalayini i Noble (1996) smatraju da je globalizacija jedan od najznačajnijih uzroka korištenja netradicionalnih pristupa mjerenju poslovne uspješnosti iz razloga što je strateški fokus mnogih poduzeća pomaknut s isključivog naglaska na ostvarenje niskih troškova proizvodnje ka povećanju kvalitete, fleksibilnosti i pravovremene isporuke. Stoga, spomenuti autori zaključuju da su tradicionalni koncepti mjerenja poslovne uspješnosti vrlo ograničeni i neprikladni novim poslovnim modelima. Taouab i Issor (2019) ukazuju kako je pronalaženje idealnog koncepta upravljanja i mjerenja poslovne uspješnosti iznimno složen problem te kako postoje značajne razlike glede upotrebe tradicionalnih i modernih pokazatelja poslovne uspješnosti. Stoga tablica 1 
pruža prikaz usporedbe osnovnih karakteristika tradicionalnih i suvremenih mjera uspješsnoti.

Tablica 1. Usporedba tradicionalnih i suvremenih mjera uspješnosti

\begin{tabular}{|c|c|}
\hline Tradicionalne mjere uspješnosti & Suvremene mjere uspješnosti \\
\hline bazirane na računovodstvenim sustavima & bazirane na strategiji poduzeća \\
\hline uglavnom financijske mjere & uglavnom nefinancijske mjere \\
\hline namijenje strateškoj razini menadžmenta & namijenjene svim zaposlenicima \\
\hline $\begin{array}{l}\text { mjere orijentirane na prošlost (tjedne ili } \\
\text { mjesečne) }\end{array}$ & $\begin{array}{l}\text { mjere orijentirane na sadašnjost (satne ili } \\
\text { dnevne) }\end{array}$ \\
\hline komplicirane, zbunjujuće i zavaravajuće & jednostavne, točne i lako se koriste \\
\hline vode ka frustraciji zaposlenika & vode ka zadovoljstvu zaposlenika \\
\hline zanemarene na najnižim operativnim razinama & $\begin{array}{l}\text { učestalo se koriste na najnižim operativnim } \\
\text { razinama }\end{array}$ \\
\hline imaju zadani (fiksni) format & nemaju zadani (fiksni) format \\
\hline ne mijenjaju se među lokacijama & variraju među lokacijama \\
\hline ne mijenjanju se protekom vremena & mijenjaju se protokom vremena \\
\hline namijenjene uglavnom za kontrolu uspješnosti & namijenjene unapređenju uspješnosti \\
\hline nisu primjenjive za JIT, TQM, RPR, OPT itd. & primjenjive za JIT, TQM, RPR, OPT itd. \\
\hline sprečavaju kontinuirana unapređenja & podupiru kontinuirana unapređenja \\
\hline
\end{tabular}

Izvor: Taouab i Issor (2019: 98).

\section{Poslovna uspješnost u poduzetničkom kontekstu}

Kao što je u prethodnom poglavlju spomenuto, znanstvena literatura ne pruža jednoznačnu odrednicu koje bi mjere bili prikladne kako bi se utvrdila razina poslovne uspješnosti poduzeća, već se koriste razne mjere, kako objektivne, tako i subjektivne ${ }^{1}$ te financijske i nefinancijske prirode (Vij i Bedi, 2012). Stoga, nameće se pitanje koje bi mjere uspješnosti trebalo koristiti prilikom istraživanja i određivanja poslovne uspješnosti. Bi li se trebale koristiti isključivo financijske mjere kao što su profitabilnost, povrat na imovinu, rast prodaje i slično ili isključivo nefinancijske mjere kao što su: tržišni udio, zadovoljstvo vlasnika, društveno odgovorno poslovanje ili je pak potrebno promatrati financijske i nefinancijske mjere zajedno s obzirom na višedimenzionalnu

1 Smatra se da su objektivne mjere uspješnosti prikladnije pri određivanju poslovne uspješnosti nego su to subjektivne mjere, međutim do objektivnih mjera nije lako doći zato što ispitanici (najčešće vlasnici i/ili strateška razina menadžmenta) nisu voljni dijeliti osjetljive poslovne informacije (Dess i Priem, 1995). S druge strane, ispitanici su spremniji dijeliti vlastite subjektivne procjene poslovne uspješnosti, koje međutim pate od manjka pouzdanosti (Wiklund i Shepherd, 2005). 
prirodu koncepta poslovne uspješnosti (Lumpkin i Dess, 1996; Wiklund i Shepherd, 2005; Verbeeten, 2005). U tablici 2 prikazani su najznačajniji pokazatelji poslovne uspješnosti suvremenih poduzeća te je u nastavku teksta pružen detaljan prikaz odabranih suvremenih pristupa proučavanju poslovne uspješnosti.

Tablica 2. Pokazatelji, kriteriji i mjere poslovne uspješnosti

\begin{tabular}{|c|c|c|c|}
\hline Pokazatelji & Kriteriji & Mjere & Pribavljanje informacija \\
\hline $\begin{array}{l}\text { zadovoljstvo } \\
\text { kupaca }\end{array}$ & $\begin{array}{l}\text { percepcije i mišljenja, } \\
\text { pritužbe i povrati } \\
\text { robe,preporuke }\end{array}$ & $\begin{array}{c}\text { stupanj slaganja s izjavom, } \\
\text { broj grešaka,trošak rješenja } \\
\text { problema }\end{array}$ & $\begin{array}{l}\text { fokus grupe i mjerne } \\
\text { skale }\end{array}$ \\
\hline $\begin{array}{l}\text { zadovoljstvo } \\
\text { zaposlenika }\end{array}$ & $\begin{array}{l}\text { moral, uvrede, prihod i } \\
\text { zadržana dobit }\end{array}$ & $\begin{array}{c}\text { prosječna vrijednost ankete, } \\
\text { broj grešaka u godini dana, } \\
\text { trošakprivlačenja novog } \\
\text { kadra }\end{array}$ & $\begin{array}{c}\text { ankete, fokus grupe, } \\
\text { razgovori }\end{array}$ \\
\hline tržišni udio & $\begin{array}{l}\text { usporedba ostvarenog } \\
\text { s potencijalnim ili s } \\
\text { konkurencijom }\end{array}$ & $\begin{array}{l}\text { novčani iznos prodaje, broj } \\
\text { prodanih proizvoda,trošak } \\
\text { unapređenja usluge }\end{array}$ & $\begin{array}{l}\text { istraživanje tržišta, } \\
\text { industrijski indeksi }\end{array}$ \\
\hline produktivnost & $\begin{array}{l}\text { vrijeme izrade, } \\
\text { proizvedena količina, } \\
\text { vrijeme procesa, } \\
\text { vrijemeciklusa }\end{array}$ & $\begin{array}{l}\text { postotak vremena, veličina } \\
\text { proizvodnog jaza, indirektni } \\
\text { troškovirealizacije }\end{array}$ & $\begin{array}{l}\text { evidencija potrebnog } \\
\text { vremena, evidencija } \\
\text { rada, arhiva rezultata }\end{array}$ \\
\hline $\begin{array}{l}\text { pokazatelji } \\
\text { proizvoda }\end{array}$ & $\begin{array}{l}\text { trošak, stopa povrata } \\
\text { proizvoda, varijanca, } \\
\text { mišljenje kupaca, kal }\end{array}$ & $\begin{array}{l}\text { trošak izrade proizvoda, } \\
\text { standardna devijacija,direktni } \\
\text { i indirektni troškovi kala }\end{array}$ & $\begin{array}{l}\text { financije, statistička } \\
\text { kontrola procesa, fokus } \\
\text { grupe }\end{array}$ \\
\hline $\begin{array}{l}\text { pokazatelji } \\
\text { zaposlenika }\end{array}$ & $\begin{array}{l}\text { prinos, gubitak, vrijeme } \\
\text { rada, ispunjenje ciljeva, } \\
\text { trošak supervizije }\end{array}$ & $\begin{array}{c}\text { postotak realizacije, omjer } \\
\text { menadžera i zaposlenika, } \\
\text { direktni iindirektni troškovi } \\
\text { realizacije }\end{array}$ & $\begin{array}{c}\text { statistička kontrola } \\
\text { procesa, evidencija } \\
\text { vremena, planovi, } \\
\text { budžeti }\end{array}$ \\
\hline $\begin{array}{l}\text { financijska } \\
\text { uspješnost }\end{array}$ & $\begin{array}{c}\text { fiksni i varijabilnitroškovi, } \\
\text { marža, stopa rasta, trošak } \\
\text { prodaje,trošak usluge }\end{array}$ & $\begin{array}{l}\text { omjeri, zarada po } \\
\text { jediniciproizvoda }\end{array}$ & $\begin{array}{c}\text { dnevni } \\
\text { izvještaji,pridržavanje } \\
\text { budžeta, analiza prodaje }\end{array}$ \\
\hline usklađenost & formalni zahtjevi i izvještaji & $\begin{array}{l}\text { količina, vrijednost, broj } \\
\text { grešaka }\end{array}$ & $\begin{array}{c}\text { kontrola kvalitete, prijava } \\
\text { kvarova i grešaka }\end{array}$ \\
\hline rast & trening i plan sukcesije & $\begin{array}{c}\text { broj provedenih } \\
\text { trening programa, broj } \\
\text { personaliziranih treninga, } \\
\text { trošak po zaposleniku, stopa } \\
\text { zadržavanjazaposlenika }\end{array}$ & $\begin{array}{c}\text { ostvaren nasuprot } \\
\text { planiranom, promjene u } \\
\text { bazama podataka }\end{array}$ \\
\hline
\end{tabular}

Izvor: Hale (2007: 209).

\subsection{Računovodstveni/financijski pristup}

Računovodstvene mjere poslovne uspješnosti predstavljaju tradicionalno uporište $u$ kvantitativnom pristupu mjerenja uspješnosti poslovanja poduzeća temeljenog na financijskim podacima i pokazateljima. Računovodstvene mjere uspješnosti imaju tri osnovne zadaće koje moraju ispuniti (Neely, 2007). Prva zadaća govori kako 
računovodstvene mjere predstavljaju alat financijskog menadžmenta čija je osnovna zadaća korištenje financijskih resursa na efikasan i efektivan način. Druga zadaća promatra ulogu financijske uspješnosti kao jednog od osnovnih ciljeva poslovanja, pri čemu se računovodstvene mjere koriste kao pokazatelji realizacije definiranih poslovnih ciljeva. Treća zadaća promatra ulogu računovodstvenih mjera kao mehanizma motivacije $i$ kontrole s obzirom na da financijske informacije pružaju uvid u upravljanje specifičnim poslovnim operacijama.

Primarna zadaća svakog poduzeća je pridržavajući se vlastitih financijskih ograničenja ostvariti očekivani povrat ulaganja svojim vlasnicima. Stoga se zadaća financijske funkcije odnosi na upravljanje i kontroliranje resursima kako se financijska ograničenja ne bi prekoračila. Financijsko planiranje i financijska kontrola predstavljaju osnovni element sveukupnog upravljačkog procesa koji se provodi izradom financijskih planova, a u kojima su istaknuti financijski ciljevi koje je potrebno realizirati kako bi poduzeće bilo u mogućnosti izvršavati sve svoje obveze (Orsag, 2011).

Fokusirani pristup analizi uspješnosti moguće je provesti analizom pojedinačnih financijskih pokazatelja pri čemu je bitno voditi računa o svrsi njihova sastavljanja. Primjerice, ako postoji zabrinutost u vezi s novčanim tokovima i likvidnosti, potrebno je analizirati pokazatelje likvidnosti, ako se postavlja pitanje u kojoj se mjeri poduzeće financira tuđim izvorima sredstava potrebno je koristiti pokazatelje zaduženosti itd. Općenito govoreći, analiza uspješnosti bazirana na financijskim pokazateljima podrazumijeva da su u poslovanju zadovoljena dva kriterija: kriterij sigurnosti, koji se tumači pokazateljima likvidnosti i zaduženosti te kriterij uspješnosti, koji se tumači pokazateljima ekonomičnosti, profitabilnosti i investiranja (Žager et al., 2017). Važno je napomenuti kako pokazatelji sami za sebe ne govore puno, već da bi se mogla donijeti kvalitetna odluka o tome jesu li veličine određenih pokazatelja zadovoljavajuće ili ne, potrebno ih je usporediti s određenim standardnim veličinama i sagledati ih kao cjelinu uspoređujući ih s ostalim financijskim pokazateljima.

Unazad dvadesetak godina vidljivo je da računovodstvene mjere same po sebi nisu dovoljne, već je pored njih potrebno uključiti i mjere kojima se iskazuju utjecaji raznih nosioca uspješnosti, kao što su: kratkoročna profitabilnost, tržišni udjel, produktivnost, razvoj zaposlenika, odnosi s javnošću itd. (Verbeeten, 2005). Elementi bilo kojeg financijskog pokazatelja mogu se definirati i interpretirati na mnoštvo različitih načina, pri čemu je procjenu potrebno bazirati na njihovoj prikladnosti specifičnoj namjeni. Čak i onda kada su pokazatelji jasno konceptualno definirani, i dalje postoji problem samog mjerenja transakcija na kojima se navedeni pokazatelji zasnivaju. Iz tog su razloga razvijeni razni drugi pristupi mjerenja uspješnosti, kao što su balanced scorecard, ekonomska dodana vrijednost, six sigma model itd. (Vrdoljak Raguž, 2010). 


\subsection{Marketinški pristup}

Marketing se u kontekstu poslovne uspješnosti odnosi na provođenje onih aktivnosti kojima se stimulira, provodi ili ubrzava prodaja (Homburg et al., 2012). Procijeniti uspješnost marketinških aktivnosti nije nimalo lagan zadatak. Za razliku od internih mjera uspješnosti, marketinška uspješnost u velikoj mjeri ovisi o eksternim čimbenicima koji se ne nalaze pod kontrolom poduzeća, kao što su kupci, dobavljači i posrednici (Liang i Gao, 2020). Štoviše, može se kazati da marketinške aktivnosti predstavljaju poveznicu između internih procesa i eksternih igrača (Lamberti i Noci, 2010). Mjerama marketinške uspješnosti nastoji se procijeniti (1) u kojoj su mjeri osvojene i zadržane preferencije kupaca, (2) u kojoj mjeri one pridonose povećanju prodaje te (3) na koji način utječu na sveukupnu poslovnu uspješnost poduzeća (Liang i Gao, 2020). U posljednje vrijeme na mjere marketinške uspješnosti snažno su utjecale nove marketinške perspektive i paradigme (Lamberti i Noci, 2010). Posebice se to odnosi na odmak od transakcijskog marketinga prema marketingu odnosa zato što je fokus transakcijskog marketinga stavljen na maksimizaciju jednokratnih transakcija, dok se marketing odnosa fokusira na stvaranje dugoročnih odnosa s kupcima koji kontinuirano pridonose profitabilnosti poduzeću (Homburg et al., 2012).

Marketinške aktivnosti uglavnom se mjere u troškovnim i vremenskim izrazima te se povezuju s intermedijarnim pokazateliima, kao što su informiranost, upoznatost, preferencije, cijena i dostupnost proizvoda (Liang i Gao, 2020) te finalnim pokazateljima iskazanim u terminima produktivnosti ili povrata na investicije (Srinivasan et al., 2009). Govoreći o finalnim pokazateljima marketinških aktivnosti najpopularnije mjere odnose se na prodaju i profitabilnost, a u novije vrijeme sve se više povezuju s novčanim tokovima i pokazateljima tržišta kapitala, kao što su cijene dionica, tržišna kapitalizacija, Tobinov q pokazatelj itd. (Kumar i Petersen, 2004; Srinivasan et al., 2009). Odmakom od tradicionalnih pokazatelja marketinške uspješnosti i postepenim razvojem novih pokazatelja, poduzeća su u proteklih dvadesetak godina intenzivnije počela koristiti različite druge pokazatelje, kao što su zadovoljstvo kupaca, lojalnost kupaca, upravljanje odnosom s kupcima itd. (Lamberti i Noci, 2010).

Nabrojavši suvremene pokazatelje marketinške uspješnosti može se zaključiti da oslanjanje na pojedine pokazatelje uspješnosti nije dovoljno, već je potrebno izgraditi cjelokupan sustav mjerenja uspješnosti koji će strateški uskladiti marketinške aktivnosti s ključnim ciljevima poduzeća. Dakle, izgradnja efikasnog sustava marketinške uspješnosti iznimno je težak i zahtjevan proces koji ovisi o nizu faktora, kao što su marketinška strategija poduzeća, korporativni kontekst, poslovno okruženje, dostupnost informacija, stavovi top menadžmenta, industrijske norme itd. Također, izgradnja efikasnog sustava marketinške uspješnosti ovisi i o zahtjevima i potrebama raznih dionika koji imaju svoje interese glede prirode mjerenja i iskazivanja uspješnosti poslovanja (Homburg et al., 2012; Liang i Gao, 2020). 


\subsection{Operativni pristup}

Operativni pristup mjerenju uspješnosti tradicionalno podrazumijeva standardne pokazatelje operativne uspješnosti, kao što su kratki proizvodni ciklusi, superiorna kvaliteta proizvoda, pouzdana i pravovremena dostava, sposobnost brze proizvodnje novih proizvoda, prilagodliivost volumena proizvodnje, niski troškovi, niska razina investicija itd. (Tsikriktsis, 2007). U današnjim uvjetima globalizacije obilježenih sve većim umrežavanjem poduzeća, naglasak je stavljen na uspješnost operativnih aktivnost glede pružanja usluga pri čemu se na mjerenje operativne uspješnosti više ne gleda proučavanjem pojedinih pokazatelja, već se primjenjuje sofisticiran i sveobuhvatan strateški pogled svih elemenata operativnih aktivnosti gdje je nužno provoditi kompromise između pojedinih pokazatelja uspješnosti. Stoga, suvremen operativni pristup mjerenju poslovne uspješnosti proučava interakciju između pet osnovnih dimenzija operativne uspješnosti: kvalitete, ovisnosti, brzine, fleksibilnosti i troškova (Neely, 2007).

Kada se govori o interakciji pet dimenzija operativne uspješnosti potrebno je imati na umu da su one multidimenzionalne naravi. Tako se primjerice kvaliteta ne odnosi isključivo na usklađenost proizvoda njegovim specifikacijama, već ona obuhvaća i druge elemente poput koliko dobro proizvod ispunjava svoju primarnu funkciju, koja dodatna obilježja proizvod posjeduje, koliko dugo proizvod može raditi prije nego postane tehnički zastarjeo, koliko je jednostavno služiti se proizvodom, estetike, percipirane kvalitete te odnosa cijene i kvalitete koju proizvod pruža kupcu. Pri mjerenju kvalitete koriste se razne tehnike kao što su: upravljanje potpunom kvalitetom (TQM), statistička kontrola procesa, six sigma model itd. (Vrdoljak Raguž, 2010). Brzina i pouzdanost mogu se promatrati konceptima just in time sustava te optimizacije tehnološke proizvodnje (OPT). Troškovi se mogu promatrati putem $\mathrm{ABC}$ metode, a fleksibilnost se može promatrati kao broj komponenti koje se koriste u proizvodnji, broj zamjena komponenti u određenom vremenskom periodu, broj dizajnerski promjena učinjenih u određenom vremenskom periodu itd. (Kumar i Petersen, 2004; Vrdoljak Raguž, 2010).

U novije vrijeme operativna uspješnost poslovanja sve se više promatra kroz prizmu potrebe usuglašavanja operativnih aktivnosti sa strategijom i strateškim ciljevima poduzeća. Iz te perspektive proizašli su razni moderni pristupi mjerenja operativne uspješnosti kao što su: piramida uspješnosti, matrica mjerenja uspješnosti, matrica pokazatelja uspješnosti (balanced scorecard) i prizma uspješnosti (Vrdoljak Raguž, 2010). Pored usklađivanja mjera uspješnosti sa strategijom poduzeća, počeli su se razvijati i pokazatelji uspješnosti koji u obzir uzimaju i okolinu poduzeća. Dva najznačajnija pristupa stavljanja poduzeća u odnos s njegovim eksternim okruženjem su benchmarking i lanaci nabave. Također, razvojem raznih softwareskih rješenja poput 
EPOS-a i ERP-a moguće je prikupljanje mnoštva podataka koji predstavljaju osnovu mjerenja i nadziranja raznih oblika pokazatelja operativne uspješnosti (Neely, 2007).

\subsection{Pristup upravljanja lancem dobave}

Promatranje koncepta uspješnosti iz perspektive upravljanja cjelokupnim lancem vrijednosti polazi od pretpostavke kako poduzeća sve više postaju ovisna jedna o drugima pri čemu ona tvore određene vrste mrežnih odnosa sa svojim dobavljačima, kupcima, konkurentima i ostalim tržišnim sudionicima (Pipunić i Grubišić, 2014). U takvom okruženju uspjeh jednog poduzeća ovisi o uspjehu ostalih poduzeća koja su dio njegove poslovne mreže. Upravljanje lancem dobave pruža mogućnost stvaranja sinergijskih učinaka integracije i upravljanja internim i eksternim aktivnostima (Gunasekaran i Kobu, 2007). Zadatak upravljanja lancem dobave je povećanje uspješnosti svih poslovnih procesa te predstavlja novi oblik upravljanja poslovnim odnosima s ostalim članovima lanca dobave (Lambert et al., 1998). U literaturi se nažalost ne mogu pronaći jasne mjere poslovne uspješnosti kojima se objedinjuje uspješnost cjelokupnog lanca dobave. Elrod et al., (2013) smatraju kako se u većini poduzeća uglavnom koriste određeni pokazatelji fokusirani na interne aktivnosti logistike, kao što su vrijeme isporuke, vrijeme utovara, obrtaj zaliha itd. Međutim, ti pokazatelji nisu u stanju odgovoriti koliko dobro i koliko efikasno ključni poslovni procesi cjelokupnog lanca dobave zadovoljavaju potrebe kupaca te u kojoj su mjeri oni pokretači nove vrijednosti i profitabilnosti (Lambert et al., 1998).

Može se zaključiti da je nužno strukturirati aktivnosti/procese unutar te između poduzeća da bi se ostvarila superiorna konkurentska prednost i profitabilnost. Zatim je potrebno integrirati poslovne procese s ključnim igračima unutar cjelokupnog lanca dobave kako ne bi došlo do rasipanja vrijednih resursa te u konačnici, da bi upravljanje lancem dobave bilo uspješno potrebno je uspostaviti dobru koordinaciju aktivnosti unutar poduzeća (Gunasekaran i Kobu, 2007). Dakle, pristup mjerenju uspješnosti promatran iz perspektive upravljanja lancem dobave zasniva se na izgradnji mudltidimenzionalnog modela koji će biti skrojen prikladno za svako pojedino poduzeće cjelokupnog lanca dobave ovisno o okruženju u kojem posluje te o položaju koji zauzima unutar samog lanca dobave (Ahmad et al., 2017).

\section{Zaključak}

Detaljnim pregledom literature naglašeni su nalazi mnogih znanstvenih istraživanja koji ukazuju na nepostojanje konsenzusa o jedinstvenoj konceptualizaciji poslovne uspješnosti. Iz prethodno analiziranih i prezentiranih empririjskih istraživanja vidljiv je nedostatak dosljednosti pri korištenju mjera kojima bi se na jasan i sveobuhvatan način mogao konceptualizirati sam koncept poslovne uspješnosti. Štoviše, navedena 
empirijska istraživanja jasno ukazaju na multidimenzionalnu prirodu koncepta poslovne uspješnosti, međutim ne pružaju suglasnost o tome koje točno dimenzije čine koncept poslovne uspješnosti, niti kako ih je moguće mjeriti.

Nadalje, u radu je pružen osnovni pregled prednosti i nedostataka različitih mjera uspješnosti, pri čemu nije identificirana jedinstvena kategorija ili skup mjera koji bi adekvatno konceptualizirao poslovnu uspješnost. Stoga je potrebno provoditi daljnja istraživanja kako bi se utvrdilo koje kategorije, pojedinačno ili skupno, pružaju najpotpuniju konceptualizaciju poslovne uspješnosti. Rad također ukazuje na nužnost korištenja različitih metrika ovisno o kontekstu te ovisno o vremenskom okviru mjerenja poslovne uspješnosti. Drugim riječima, poslovna uspješnost trebala bi se redovito pratiti tijekom dužeg vremenskog razdoblja korištenjem različitih metrika ovisno o specifičnostima promatranog vremenskog okvira.

$\mathrm{U}$ radu je prikazan detaljan pregled literature o povijesnom razvoju koncepta poslovne uspješnosti, pri čemu su pruženi tradicionalni i suvremeni pogledi na konceptualizaciju poslovne uspješnosti. Također, pružen je pregled različitih perspektiva proučavanja poslovne uspješnosti iz čega se može jasno zaključiti kako postoje mnogi pravci mišljenja o tome kako treba mjeriti poslovnu uspješnost, pri čemu do danas nije razvijen jedinstven model, niti jedinstven skup mjera. Radom je također pružen detaljan opis koncepta poslovne uspješnosti unutar poduzetničkog konteksta, pri čemu je naglasak stavljen na najznačajnije pristupe proučavanja poslovne uspješnosti, kao što su računovodstveni, financijski, marketinški, operativni i logistički pristup.

Ukratko, može se zaključiti da literatura i dalje ne pruža jedinstven i nedvosmislen pogled koja bi mjera bila „najbolja” mjera poslovne uspješnosti, niti pruža jasno definiran model kojim bi se poslovna uspješnost mogla u potpunosti iskazati. Rad je namijenjen široj akademskoj i poslovnoj zajednici zainteresiranoj za proučavanje koncepta poslovne uspješnost i njezine teorijske i praktične primjene.

\section{Literatura}

1. Abu-Jarad, I. Y., Yusof, N. A. i Nikbin, D. 2010. A review paper on organizational culture and organizational performance. International journal of business and social science, 1 (3): 26-46.

2. Ahmad, N. K. W., de Brito, M. P., Rezaei, J. i Tavasszy, L. A. 2017. An integrative framework for sustainable supply chain management practices in the oil and gas industry. Journal of Environmental Planning and Management, 60 (4): 577-601.

3. Ansoff, H. I. 1965. Corporate strategy: An analytic approach to business policy for growth and expansion. McGraw-Hill Companies.

4. Antoncic, B. i Hisrich, R. D. 2003. Clarifying the intrapreneurship concept. Journal of small business and enterprise development, 10 (1): 7-24. 
5. Brush, C. G. i Vanderwerf, P. A. 1992. A comparison of methods and sources for obtaining estimates of new venture performance. Journal of Business venturing, 7 (2): 157170 .

6. Carton, R. B. i Hofer, C. W. 2006. Measuring organizational performance: Metrics for entrepreneurship and strategic management research. Edward Elgar Publishing.

7. Cavusgil, S. T. i Zou, S. 1994. Marketing strategy-performance relationship: an investigation of the empirical link in export market ventures. Journal of marketing, 58 (1): 1-21.

8. Chakravarthy, B. S. 1986. Measuring strategic performance. Strategic management journal, 7 (5): 437-458.

9. Dess, G. G. i Robinson Jr. R. B. 1984. Measuring organizational performance in the absence of objective measures: the case of the privately-held firm and conglomerate business unit. Strategic management journal, 5 (3): 265-273.

10. Drucker, P. F. 1954. The Practice of Management. New York: Harper \& Row.

11. Elrod, C., Murray, S. i Bande, S. 2013. A review of performance metrics for supply chain management. Engineering Management Journal, 25 (3): 39-50.

12. Freeman, R. E. 1984. Strategic Management: A Stakeholder Approach. Boston MA: Pitman.

13. Ghalayini, A. M. i Noble, J. S. 1996. The changing basis of performance measurement. International journal of operations and production management, 16 (8): 63-80.

14. Gimbert, X., Bisbe, J. i Mendoza, X. 2010. The role of performance measurement systems in strategy formulation processes. Long Range Planning, 43 (4): 477-497.

15. Gunasekaran, A. i Kobu, B. 2007. Performance measures and metrics in logistics and supply chain management: a review of recent literature (1995-2004) for research and applications. International journal of production research, 45 (12): 2819-2840.

16. Hale, J. 2007. The performance consultant's fieldbook. John Wiley and Sons, San Francisco, CA.

17. Homburg, C., Artz, M. i Wieseke, J. 2012. Marketing performance measurement systems: does comprehensiveness really improve performance? Journal of marketing, 76 (3): $56-77$.

18. Ittner, C. D. i Larcker, D. F. 2003. Coming up short on nonfinancial performance measurement. Harvard business review, 81 (11): 88-95.

19. Kumar, V. i Petersen, J. A. 2004. Maximizing ROI or profitability. Marketing Research, 16 (3): 28-34.

20. Kumarasinghe, S. i Hoshino, Y. 2010. The role and perceptions of middle managers and their influence on business performance: The case of Sri Lanka. International Business Research, 3 (4): 3-16.

21. Lambert, D. M., Cooper, M. C. i Pagh, J. D. 1998. Supply chain management: implementation issues and research opportunities. The international journal of logistics management, 9 (2): 1-20.

22. Lamberti, L. i Noci, G. 2010. Marketing strategy and marketing performance measurement system: Exploring the relationship. European Management Journal, 28 (2): 139_ 152.

23. Lebans, M. i Euske, K. 2006. A conceptual and operational delineation of performance. Business Performance Measurement. Cambridge University Press.

24. Liang, X. i Gao, Y. 2020. Marketing performance measurement systems and firm performance: Are marketing capabilities the missing links? European Journal of Marketing, 54 (4): 885-907. 
25. Lumpkin, G. T. i Dess, G. G. 1996. Clarifying the entrepreneurial orientation construct and linking it to performance. Academy of management Review, 21 (1): 135-172.

26. Marr, B. i Schiuma, G. 2003. Business performance measurement-past, present and future. Management decision, 41 (8): 680-687.

27. Mečev, D. i Grubišić, D. 2020. Organizacijska kultura i poslovna uspješnost poduzeća: perspektiva suparničkih vrijednosti u kontekstu hrvatskog ict sektora. Ekonomska misao i praksa, 29 (2): 327-346.

28. Murphy, G. B., Trailer, J. W. i Hill, R. C. 1996. Measuring performance in entrepreneurship research. Journal of business research, 36 (1): 15-23.

29. Neely, A. 2007. Business Performance Measurement. Cambridge University Press, UK.

30. Neely, A., Gregory, M. i Platts, K. 2005. Performance measurement system design: A literature review and research agenda. International journal of operations and production management, 25 (12): 1228-1263.

31. Ogunsiji, A. S. i Ladanu, W. K. 2017. A theoretical study of performance measures in the strategic and corporate entrepreneurship of firms. International Journal of Life Sciences (IJLS), 1 (1): 49-57.

32. Orsag, S. 2011. Vrijednosni papiri. Investicije i instrumenti financiranja. Sarajevo: Revicon.

33. Pipunić, A. i Grubišić, D. 2014. Suvremeni pristupi poboljšanjima poslovnih procesa i poslovna uspješnost. Ekonomska misao i praksa, (2): 541-572.

34. Porter M. 1985. Competitive advantage: creating and sustaining superior performance. Free Press.

35. Siepel, J. i Dejardin, M. 2020. How do we measure firm performance? A review of issues facing entrepreneurship researchers. Handbook of Quantitative Research Methods in Entrepreneurship.

36. Srinivasan, S., Pauwels, K., Silva-Risso, J. i Hanssens, D. M. 2009. Product innovations, advertising, and stock returns. Journal of Marketing, 73 (1): 24-43.

37. Tangen, S. 2004. Performance measurement: from philosophy to practice. International Journal of Productivity and Performance Management, 53 (8): 726-737.

38. Taouab, O. i Issor, Z. 2019. Firm performance: Definition and measurement models. European Scientific Journal, 15 (1): 93-106.

39. Tsikriktsis, N. 2007. The effect of operational performance and focus on profitability: A longitudinal study of the US airline industry. Manufacturing \& Service Operations Management, 9 (4): 506-517.

40. Venkatraman, N. i Ramanujam, V. 1986. Measurement of business performance in strategy research: A comparison of approaches. Academy of management review, 11 (4): 801-814.

41. Verbeeten, F. H. M. 2005. New' Performance Measures: Determinants of Their Use and Their Impact on Performance. https://ssrn.com/abstract=902729.

42. Vij, S. i Bedi, H. S. 2012. Relationship between entrepreneurial orientation and business performance: A review of literature. The IUP Journal of Business Strategy, 9 (3): 17-31.

43. Vij, S. i Bedi, H. S. 2016. Are subjective business performance measures justified?. International Journal of Productivity and Performance Management, 65: 603-621.

44. Vrdoljak Raguž, I. 2010. Specifičnosti metodoloških pristupa mjerenju uspješnosti poslovanja kvalitativnim pokazateljima. Poslovna izvrsnost, 4 (2): 107-117. 
45. Waggoner, D. B., Neely, A. D. i Kennerley, M. P. 1999. The forces that shape organisational performance measurement systems: An interdisciplinary review. International journal of production economics, 60: 53-60.

46. Wiklund, J. 1999. The sustainability of the entrepreneurial orientation - performance relationship. Entrepreneurship theory and practice, 24 (1): 37-48.

47. Wiklund, J. i Shepherd, D. 2005. Entrepreneurial orientation and small business performance: a configurational approach. Journal of business venturing, 20 (1): 71-91.

48. Žager, L. et al. 2017. Analiza financijskih izvještaja, treće izmijenjeno i dopunjeno izdanje. Zagreb: Hrvatska zajednica računovođa i financijskih djelatnika.

\section{Contemporary approaches in observing business performance from an entrepreneurial perspective}

Abstract

Measuring business performance still represents a significant challenge for both the scientific and business communities. Empirical research clearly indicates the multidimensional aspect of business performance, however does not provide an agreement which dimensions constitute the concept itself. The objectives of the paper are following: (1) to present a detailed literature review on the historical development of the business performance as a concept taking into account traditional and contemporary perspectives, (2) to provide an overview of the main advantages and disadvantages of various performance measures, (3) to present a detailed description of business performance within an entrepreneurial context where the emphasis is placed on the most significant approaches to researching the concept of business performance. It can be concluded that the literature still does not provide a unique and unambiguous view of what is the best; measure of business performance, nor does it provide a clearly defined model by which business performance could be entirely explained. The paper is intended for the wider academic and business community interested in researching the concept of business performance, including its theoretical and practical applications.

Key words: business performance, performance indicators, multidimensionality, entrepreneurship 